\title{
Correspondence
}

To the Editors

\section{Childhood case histories that may have misled you}

\author{
Sri Lanka Journal of Paediatrics, 2008; 37: 134
}

It is standard medical student teaching that history taking forms the foundation on which the diagnostic process stands. The different components of the history are vital for pronouncing prognosis too. In addition, in the field of paediatrics, the social history and birth history are of predictive value for the final outcome of childhood itself. It is however important that paediatricians, adept as they may be at eliciting history, are never prophetic. It is in this light that these histories are reproduced for your consideration.

\section{Case history 1}

A boy is born in a small village, at a time when a war is raging. His father dies when he is just past infancy. Denied a father's love, he loses his mother too at the age of three years, when she remarries and leaves the village entrusting him to a feeble old grandmother who sends him to the local school. At the age of fourteen his stepfather whom he hardly knows dies. Left with the worries of a farm, his mother, withdraws him from school, and so this fourteen year old spends his days counting heads of cattle and ploughing parallel furrows on the farm.

Based on this social history what chances would you give this 14 year old farm help of a sound education?

Would you consider it likely that he becomes a great mathematician who would work out the binomial theorem and integral calculus, discover the principles by which the whole universe exists and moves, invent the reflecting telescope or get elected President of the Royal Society annually for twenty five consecutive years?

This was the social history of the child Isaac Newton (1642 - 1727).

\section{Case history 2}

In a country under foreign invasion and bitter oppression, a highly educated man and his wife, a headmistress of a school, live in a small overcrowded apartment in the school building given to them as part of the wife's salary. She has tuberculosis and spends long spells away from the family on "rest cures". After a reported thirteen pregnancies with only five resulting in live births she delivers her youngest, the fifth child in the school apartment and dies when the little girl is seven.

Given this obstetric history, would you have recommended family planning to this mother after her fourth pregnancy?

If yes, you would have prevented the birth of the first woman teacher and professor of Sorbonne University, the first woman in Europe to be awarded a Nobel Prize and twice Nobel Laureate in Physics and Chemistry.

This was the family history of the child Marja Sklodowska, (Marie Currie) (1867 -1934)

M P Senanayake

Professor of Paediatrics, Faculty of Medicine, Colombo 